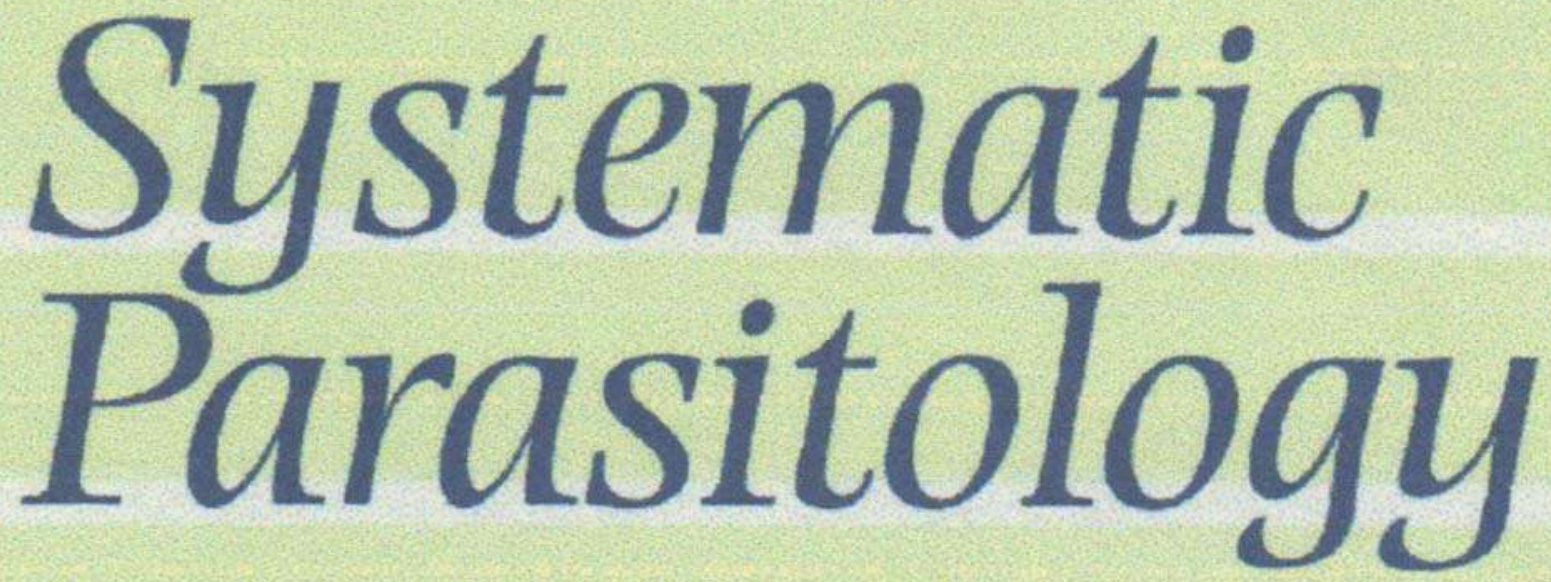

An International Journal
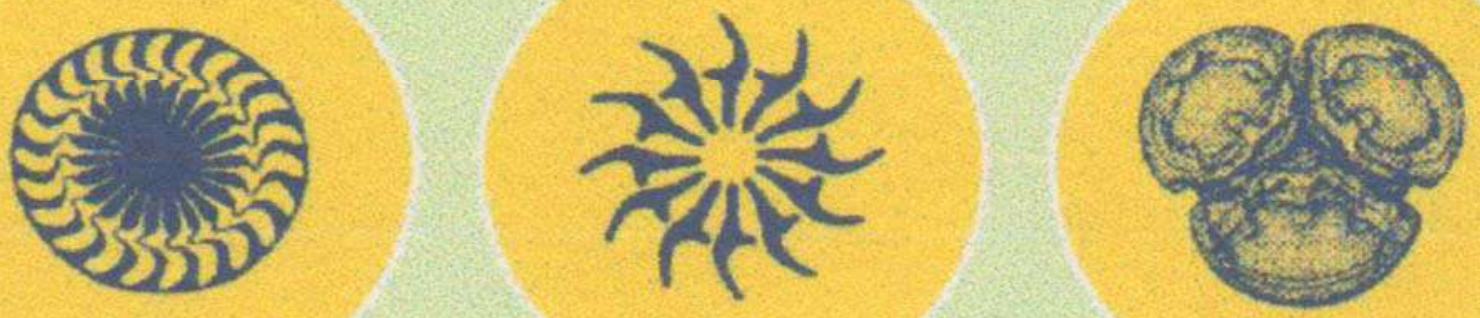

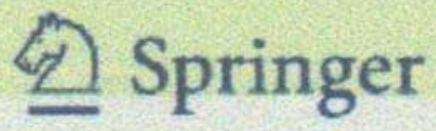




\section{Editor-in-Chief:}

\section{Aneta K. Kostadinova}

Biology Centre, Academy of Sciences of the Czech Republic, Institute of Parasitology, Branišovská 31, 37005 České Budějovice, Czech Republic

\section{Co-editors / Associate Editors:}

I. Beveridge, Veterinary Clinical Centre, University of Melbourne, Princes Highway, Werribee, Victoria 3030, Australia

G.A. Boxshall, Department of Zoology, Natural History Museum, London SW7 5BD, UK

R.A. Bray, Department of Zoology, Natural History Museum, London SW7 5BD, UK

J. Caira, Department of Ecology and Evolutionary Biology, University of Connecticut, 75 North Eagleville Road, U-43, Storrs, CN 06269-3043, USA;

T.H. Cribh, Department of Microbiology and Parasitology, University of Queensland, Brisbane Q 4072, Australia

D. W. Duszynsky, Department of Biology, University of New Mexico, Albuquerque, NM 87131, USA

B.B. Georgiev, Institute of Biodiversity and Ecosystems Research, Bulgarian Academy of Sciences, 2, Gagarin Street, 1113, Sofia, Bulgaria

D.I. Gibson, Department of Zoology, Natural History Museum, Cromwell Road, London SW7 5BD, UK

M.J. Grygier, National Taiwan Ocean University, Taiwan (R.O.C.)

P.D. Harris, Natural History Museum, University of Oslo, Oslo, Norway

D. Hunt, CABI Biosciences, UK Centre (Egham), Bakeham Lane, Egham TW20 9TY, UK

K. Jensen, Department of Ecology and Evolutionary Biology, University of Kansas, 1200 Sunnyside Ave., 5024 Haworth Hall, Lawrence, KS 66045, USA

G.C. Kearn, School of Biological Sciences, University of East Anglia, Norwich NR4 7TJ, UK

M. Kent, Department of Microbiology, Oregon State University, OR 97331-3804, USA 
H. Klompen, Ohio State University, Museum of Biological Diversity, Columbus, USA

D.C. Kritsky, College of Health Professions, Campus box 8090, Idaho State University, Pocatello, ID 83209, USA

D. T. J. Littlewood, Department of Zoology, Natural History Museum, Cromwell Road, London SW7 5BD, UK

F. Moravec, Institute of Parasitology, Academy of Sciences of the Czech Republic, Branišovská 31, 37005 České Budějovice, Czech Republic

S. Nadler, Department of Nematology, University of California, CA 95616-8668, USA

R.M. Overstreet, Gulf Coast Research, P.O. Box 7000, 703 East Beach Drive, Ocean Springs, MS 39564-7000, USA

T. Scholz, Institute of Parasitology, Academy of Sciences of the Czech Republic, Branišovská 31, 37005 České Budějovice, Czech Republic 
- Article

\section{Three new coccidians (Cyclospora, Eimeria) from eastern moles, Scalopus aquaticus (Linnaeus) (Mammalia: Soricomorpha: Talpidae) from Arkansas, USA}

Three new species of coccidians (Apicomplexa: Eimeriidae) are described from eastern moles, Scalopus aquaticus (Linnaeus) from Arkansas. Oöcysts of Cyclospora duszynskii n. sp. are subspheroidal with a smooth bi-...

Chris T. McAllister, Dagmara Motriuk-Smith, $\underline{\text { Catherine M. Kerr in Systematic Parasitology }}$ (2018)

Download PDF (730 KB) View Article

- Articie

Characterisation of a new species of Trichodorus Cobb, 1913 (Triplonchida: Trichodoridae) from Iran based on morphological and molecular data

Trichodorus zanjanensis $\mathrm{n}$. sp., collected from the rhizosphere of wild almond tree (Amygdalus scoparia Spach) in Zanjan Province, Iran, is described and illustrated based on morphological and molecular data. The ...

Ramezan Asghari, Ali Eskandari, Zahra Tanha Maafi... in Systematic Parasitology (2018)

Download PDF (1971 KB) View Article

- Article

Molecular genetic diversity of Gongylonema neoplasticum (Fibiger \& Ditlevsen, 1914) (Spirurida: Gongylonematidae) from rodents in Southeast Asia

More than a dozen Gongylonema spp. (Spirurida: Spiruroidea: Gongylonematidae) have been described from a variety of rodent hosts worldwide. Gongylonema neoplasticum (Fibiger \& Ditlevsen, 1914), which dwells in th...

Aogu Setsuda, Alexis Ribas, Kittipong Chaisiri, Serge Morand... in Systematic Parasitology (2018) 


\section{Download PDF (1166 KB) View Article}

- Article

\section{A new species of Isospora Schneider, 1881 (Apicomplexa: Eimeriidae) from the twist-necked turtle Platemys platycephala (Schneider) (Testudines: Chelidae) in Brazil}

A new coccidian species of the genus Isospora Schneider 1881 (Apicomplexa, Eimeriidae) is reported from a single specimen of chelid turtle, Platemys platycephala (Schneider, 1792), obtained in a flooded area of $\mathrm{t} .$.

Jamille Karina Coelho Correa, Emil José Hernández-Ruz... in Systematic Parasitology (2018)

Download PDF (1004 KB) Vicw Articlc

- Article

Syndesmis François, 1886 (Rhabdocoela: Umagillidae): a revisitation, with a synopsis and an identification key to species, and new molecular evidence for ascertaining the phylogeny of the group

Syndesmis François, 1886 is a genus of umagillid turbellarians comprising species which are typically endosymbionts of echinoids, i.e. sea urchins. This group is likely key in addressing the issue of transition $b$...

Francisca I. Cavaleiro, Duarte G. Frade, Luís F. Rangel... in Systematic Parasitology (2018)

Download PDF (1539 KB) View Article

- Article

\section{Two species of Phyllodistomum Braun, 1899 (Trematoda: Gorgoderidae) from Moreton Bay, Australia}

Two species of the trematode genus Phyllodistomum Braun, 1899 (Gorgoderidae) are reported infecting teleost fishes from Moreton Bay, Queensland, Australia. Phyllodistomum hyporhamphi n. sp. is described from two ...

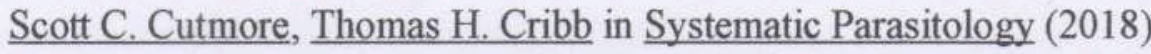


Download PDF (1481 KB) View Article

- Article

Expansion of the concept of the Opistholebetinae Fukui, 1929 (Digenea: Opecoelidae Ozaki, 1925), with Magnaosimum brooksae n. g., n. sp. from Tripodichthys angustifrons (Hollard) (Tetraodontiformes: Triacanthidae) in Moreton Bay, Australia

The Opecoelidae Ozaki, 1925, the largest trematode family, currently lacks an adequate subfamilial organisation. In particular, recent analyses have shown that the sequenced representatives of the Opistholebet...

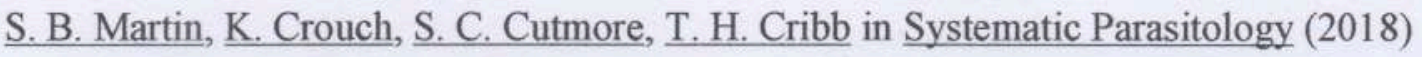

Download PDF (812 KB) View Article

- Article

Trypanosoma brucei Plimmer \& Bradford, 1899 is a synonym of T. evansi (Steel, 1885) according to current knowledge and by application of nomenclature rules

Proper application of the principles of biological nomenclature is fundamental for scientific and technical communication about organisms. As other scientific disciplines, taxonomy inherently is open to change...

$\underline{\text { Jesús Molinari, }} \underline{\text { S. Andrea Moreno in Systematic Parasitology (2018) }}$

Download PDF (402 KB) Vicw Article

- Article

Myxobolus imparfinis n. sp. (Myxozoa: Myxosporea), a new gill parasite of Imparfinis mirini Haseman (Siluriformes: Heptapteridae) in Brazil

A new species of myxozoan, Myxobolus imparfinis n. sp. is described based on material from the gills of Imparfinis mirini (Haseman) (Heptapteridae). Mature myxospores are round, measuring 7.1-8.4 (7.9 \pm 0.3$) \mu \mathrm{m} \mathrm{i...}$ 
Diego Henrique Mirandola Dias Vieira... in Systematic Parasitology (2018)

Download PDF (938 KB) View Article

- Article

\section{A new species of Steringotrema Odhner, 1911 (Trematoda: Fellodistomidae) from the New Zealand sole Peltorhamphus novaezeelandiae Günther off Kaka point in the Catlins, South Island, New Zealand}

As a part of a comprehensive survey of macroparasites of commercially exploited fish species off the coast of Otago, New Zealand, the parasite fauna of the New Zealand sole Peltorhamphus novaezeelandiae Günther w...

Gerardo Pérez-Ponce de León, Thibaut Anglade, Haseeb S. Randhawa in Systematic Parasitology (2018)

Download PDF (1060 KB) View Article

- Article

Two new species of Haplorchoides Chen, 1949 (Digenea: Heterophyidae) infecting an Australian siluriform fish, Neoarius graeffei Kner \& Steindachner

Combined morphological and molecular analyses are used to characterise two new species of Haplorchoides Chen, 1949 (Digenea: Heterophyidae) from an Australian siluriform fish. Haplorchoides maiwariensis n. sp. an...

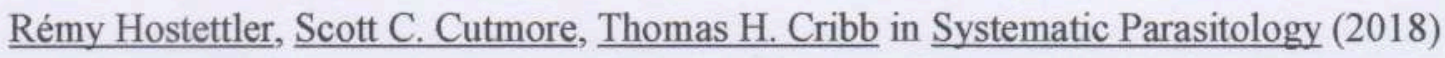

Download PDF (1005 KB) View Article

- Article

Two new gonad-infecting species of Philometra Costa, 1845 (Nematoda: Philometridae) from Trachinus spp. (Osteichthyes: Trachinidae) in the Gulf of Hammamet, Tunisia 
Based on light and scanning electron microscopical studies, two new gonad-infecting species of Philometra Costa, 1845, P. draco n. sp. and P. radiata n. sp. (Nematoda: Philometridae), are described from the marin...

Nessrine Ghanmi, David González-Solis, Lamia Gargouri in Systematic Parasitology (2018)

Download PDF (3273 KB) View Article

- Article

A new genus and species of turtle blood fluke (Digenea: Schistosomatoidea) from the Mekong snail-eating turtle, Malayemys subtrijuga (Schlegel \& Müller) (Testudines:

Geoemydidae) in Vietnam, with a reassessment of related Asiatic turtle blood flukes and molecular phylogeny

Platt sinuosus Roberts \& Bullard n. g., n. sp. (type-species) infects the kidney and mesenteric blood vessels of Mekong snail-eating turtles, Malayemys subtrijuga (Schlegel \& Müller), in the Mekong River Basin. S...

Jackson R. Roberts, Cova R. Arias, Kenneth M. Halanych... in Systematic Parasitology (2018)

Download PDF (1173 KB) View Article

- Article

Eimeria maricopensis n. sp. (Apicomplexa: Eimeriidae) from the Arizona cotton rat Sigmodon arizonae Mearns (Rodentia: Cricetidae) in central Arizona, USA

Eimeria maricopensis n. sp. (Apicomplexa: Eimeriidae) is described from 2 of 15 (13\%) Arizona cotton rats Sigmodon arizonae Mearns in Arizona, USA. Sporulated oöcysts of this new species are ovoidal to ellipsoida...

John A. Hnida in Systematic Parasitology (2018)

Download PDF $(661 \mathrm{~KB})$ View Article

- Article 
Amphibiophilus mooiensis n. sp. (Nematoda:

Amphibiophilidae), a parasite of Amietia delalandii (Duméril \& Bibron) (Amphibia: Pyxicephalidae) from South Africa

Four species of the genus Amphibiophilus Skrjabin, 1916 from pyxycephalid frogs in southern and central Africa are currently recognised as valid. Several specimens of Amphibiophilus were found in material from th...

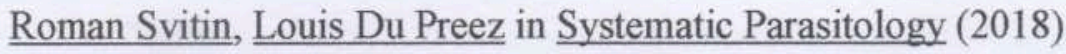

Download PDF (805 KB) View Article

- Article

Capillaria appendigera n. sp. (Nematoda: Capillariidae) from the goldbanded jobfish Pristipomoides multidens (Day) (Lutjanidae) and new records of other intestinal capillariids from marine perciform fishes off Australia

Based on light and scanning electron microscopical studies, a new nematode parasite, Capillaria appendigera n. sp. (Capillariidae), is described from the intestine of the goldbanded jobfish Pristipomoides multide...

František Moravec, Diane P. Barton in Systematic Parasitology (2018)

Download PDF (2858 KB) View Article

- Article

Expanded description of Lamproglena cleopatra Humes, 1957 (Lernaeidae: Copepoda) from Labeo spp. (Cyprinidae) with a key to species of Lamproglena von Nordmann, 1832

The occurrence of the copepod Lamproglena cleopatra Humes, 1957, parasitising freshwater fishes in the Limpopo River System is presented, along with new morphological data. This crustacean was originally describe...

Katlego D. Kunutu, Sareh Tavakol, Ali Halajian, Chantelle Baker... in Systematic Parasitology (2018)

Download PDF (3298 KB) View Article 
- Article

\section{Vampirolepis kulkinae n. sp. (Cyclophyllidea:}

Hymenolepididae) from the common noctule bat Nyctalus noctula (Schreber) (Chiroptera: Vespertilionidae) in Kazakhstan

A previously unrecognised species of hymenolepidid cestode attributable to Vampirolepis Spassky, 1954 is described based on specimens from the common noctule bat Nyctalus noctula (Schreber) (Chiroptera: Vespertil...

Tatiana A. Makarikova in Systematic Parasitology (2018)

Download PDF (1008 KB) View Article

- Article

\section{A new species of Uniclypea Bouček, 1976 (Hymenoptera: Pteromalidae) parasitic on Apoderus tranquebaricus Fabricius (Coleoptera: Attelabidae) from India with notes on biology}

One new species of parasitic wasp, Uniclypea similis n. sp. (Hymenoptera: Pteromalidae), reared from the leaf knots constructed by Apoderus tranquebaricus Fabricius (Coleoptera: Attelabidae) on the host plant Gre...

Ankita Gupta in Systematic Parasitology (2018)

Download PDF (1686 KB) View Article

- Article

Revision of Podocotyloides Yamaguti, 1934 (Digenea: Opecoelidae), resurrection of Pedunculacetabulum Yamaguti, 1934 and the naming of a cryptic opecoelid species

Despite morphological and ecological inconsistencies among species, all plagioporine opecoelids with a pedunculate ventral sucker are currently considered to belong in the genus Podocotyloides Yamaguti, 1934. We ...

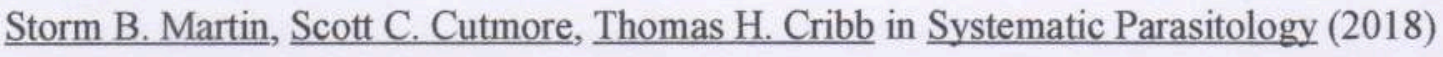
Download PDF (3048 KB) Vicw Articlc 
- Article

Dactylogyrids (Monogenoidea) infecting the gill lamellae of some beloniform fishes from Moreton Bay, Queensland, Australia, with a redescription of Hareocephalus thaisae Young, 1969 and descriptions of six new species of Hemirhamphiculus Bychowsky \& Nagibina, 1969

Three species of beloniform fishes were found infected with species of Monogenoidea Bychowsky, 1937 during a survey of the diversity of parasites infecting the fishes of Moreton Bay, Queensland, Australia. The...

Delane C. Kritsky in Systematic Parasitology (2018)

Download PDF (3284 KB) View Article

- Article

Phylogenetic relationships of the genus Armadolepis Spassky, 1954 (Eucestoda, Hymenolepididae), with descriptions of two new species from Palaearctic dormice (Rodentia, Gliridae)

Two new species of hymenolepidid cestodes belonging to the genus Armadolepis Spassky, 1954 are described from dormice (Gliridae) from the southern East European Plain and the northwestern Caucasus, Russia. Armado...

Arseny A. Makarikov, Valeriy V. Stakheev, Vasyl V. Tkach in Systematic Parasitology (2018) Download PDF (2851 KB) Vicw Article 
Molecular genetic diversity of

Gongylonema neoplasticum (Fibiger \& Ditlevsen, 1914) (Spirurida:

Gongylonematidae) from rodents in Southeast Asia

Aogu Setsuda, Alexis Ribas, Kittipong

Chaisiri, Serge Morand, Monidarin

Chou, Fidelino Malbas, Muchammad

Yunus \& Hiroshi Sato

Systematic Parasitology

An International Journal

ISSN 0165-5752

Volume 95

Combined 2-3

Syst Parasitol (2018) 95:235-247

DOI 10.1007/s11230-018-9778-0

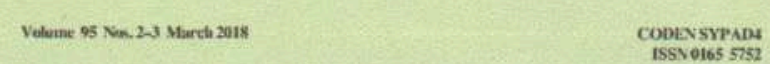

Systematic Parasitology

An International Journal
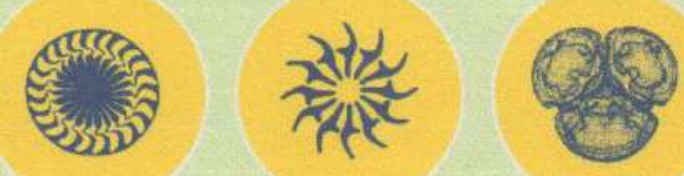

Q Springer

Springer 
Your article is protected by copyright and all rights are held exclusively by Springer Science+Business Media B.V., part of Springer Nature. This e-offprint is for personal use only and shall not be self-archived in electronic repositories. If you wish to self-archive your article, please use the accepted manuscript version for posting on your own website. You may further deposit the accepted manuscript version in any repository, provided it is only made publicly available 12 months after official publication or later and provided acknowledgement is given to the original source of publication and a link is inserted to the published article on Springer's website. The link must be accompanied by the following text: "The final publication is available at link.springer.com".

\section{型 Springer}




\title{
Molecular genetic diversity of Gongylonema neoplasticum (Fibiger \& Ditlevsen, 1914) (Spirurida: Gongylonematidae) from rodents in Southeast Asia
}

\author{
Aogu Setsuda $\cdot$ Alexis Ribas $\cdot$ Kittipong Chaisiri $\cdot$ Serge Morand $\cdot$ \\ Monidarin Chou $\cdot$ Fidelino Malbas • Muchammad Yunus • Hiroshi Sato
}

Received: 12 December 2017/ Accepted: 20 January 2018/Published online: 14 February 2018

(C) Springer Science+Business Media B.V., part of Springer Nature 2018

\begin{abstract}
More than a dozen Gongylonema spp. (Spirurida: Spiruroidea: Gongylonematidae) have been described from a variety of rodent hosts worldwide. Gongylonema neoplasticum (Fibiger \& Ditlevsen, 1914), which dwells in the gastric mucosa of rats such as Rattus norvegicus (Berkenhout) and Rattus rattus (Linnaeus), is currently regarded as a cosmopolitan nematode in accordance with global dispersion of its definitive hosts beyond Asia. To facilitate the reliable specific differentiation of local
\end{abstract}

This article is part of the Topical Collection Nematoda.

A. Setsuda $\cdot$ H. Sato $(\bowtie)$

Laboratory of Parasitology, United Graduate School

of Veterinary Science, Yamaguchi University, 1677-1

Yoshida, Yamaguchi 753-8515, Japan

e-mail: sato7dp4@yamaguchi-u.ac.jp

A. Ribas

Section of Parasitology, Department of Biology,

Healthcare and the Environment, Faculty of Pharmacy

and Food Sciences, University of Barcelona, Av. de Joan

XXIII, 27-31, 08028 Barcelona, Spain

K. Chaisiri

Department of Helminthology, Faculty of Tropical

Medicine, Mahidol University, 420/6 Ratchawithi Road,

Ratchathewi, Bangkok 10400, Thailand

S. Morand

CNRS-CIRAD ASTRE, Faculty of Veterinary

Technology, Kasetsart University, Bangkok 10900,

Thailand rodent Gongylonema spp. from the cosmopolitan congener, the genetic characterisation of G. neoplasticum from Asian Rattus spp. in the original endemic area should be considered since the morphological identification of Gongylonema spp. is often difficult due to variations of critical phenotypical characters, e.g. spicule lengths and numbers of caudal papillae. In the present study, morphologically identified $G$. neoplasticum from 114 rats of seven species from Southeast Asia were selected from archived survey materials from almost 4,500 rodents: Thailand (58 rats), Cambodia (52 rats), Laos (three rats) and

\author{
M. Chou \\ Laboratoire Rodolphe Mérieux, University of Health \\ Sciences, 73, Preah Monivong Blvd, Sangkat Sras Chak, \\ Khan Daun Penh, Phnom Penh, Cambodia \\ F. Malbas \\ Research Institute for Tropical Medicine, 9002 Research \\ Dr., Alabang, 1781 Muntinlupa, Metro Manila, \\ Philippines \\ M. Yunus \\ Department of Parasitology, Faculty of Veterinary \\ Medicine, Airlangga University, Campus C, Mulyorejo, \\ Surabaya 60115, Indonesia
}


Philippines (one rat). In addition, several specimens from four rats in Indonesia were used in the study. Nucleotide sequences of the ribosomal RNA gene (rDNA) $(5,649 \mathrm{bp})$ and the cytochrome $c$ oxidase subunit 1 gene ( $\operatorname{cox} 1)$ ( $818 \mathrm{bp}$ ) were characterised. The rDNA showed little nucleotide variation, including the internal transcribed spacer (ITS) regions. The cox 1 showed 24 haplotypes, with up to 15 (1.83\%) nucleotide substitutions regardless of parasite origin. Considering that Rattus spp. have been shown to originate from the southern region of Asia and $G$. neoplasticum is their endogenous parasite, it is reasonable to propose that the present study covers a wide spectrum of the genetic diversity of G. neoplasticum, useful for both the molecular genetic speculation of the species and the molecular genetic differentiation of other local rodent Gongylonema spp. from the cosmopolitan congener.

\section{Introduction}

Members of the genus Gongylonema Molin, 1857 (Spirurida: Spiruroidea: Gongylonematidae), are filiform nematodes dwelling in the mucosa of the upper digestive tract of a variety of mammals and birds worldwide (Yamaguti, 1961; Skrjabin et al., 1967; Lichtenfels, 1971; Anderson, 1992). The worms are characterised by verruciform thickenings, i.e. longitudinal rows of cuticular bosses, on the anterior surface of the body (Chabaud, 2009). More than a dozen nominal Gongylonema spp. have been described from rodents worldwide based on morphological criteria (Fibiger \& Ditlevsen, 1914; Kruidenier \& Peebles, 1958; Yamaguti, 1961; Skrjabin et al., 1967; Gupta \& Trivedi, 1985; Ashour \& Lewis, 1986; Diouf et al., 1997; Kinsella et al., 2016). Some of the described species require the collection and characterisation of more specimens as their characterisation was based on a limited number of worms or they were recovered from a unique body location, different from other species, as indicated by Kinsella et al. (2016).

Considering an earlier trend where many helminth species descriptions were primarily based on different isolation sources and/or some morphological uniqueness of microscopically observed worms, it would be prudent to discern the taxonomic relationships of local Gongylonema spp. isolated from different rodent hosts in the world, as has been done for G. pulchrum Molin,
1857 with many synonymised taxa based on crossinfection experiments (Ransom \& Hall, 1915; Baylis et al., 1926a, b; Schwartz \& Lucker, 1931; Lucker, 1932) or meticulous morphological analyses (Schwartz \& Lucker, 1931; Lichtenfels, 1971). These strategies for taxonomical revision can be hampered by the practical difficulties of worm collection from wild rodent hosts and/or collection of wild rodents for experimental infection purposes; however, molecular genetic analyses now offer an alternative approach for such a task.

Nucleotide sequencing of the ribosomal RNA gene (rDNA) and partial cytochrome $c$ oxidase subunit 1 (cox 1$)$ region of mitochondrial DNA (mtDNA) of specimens of Gongylonema isolated from different mammalian hosts has enabled us to differentiate $G$. nepalensis Setsuda, Da, Hasegawa, Behnke, Rana \& Sato, 2016 from G. pulchrum and understand their possible natural transmission dynamics in domestic and wild ruminants (Sato, 2009; Makouloutou et al., 2013a, b; Setsuda et al., 2016; Varcasia et al., 2017). We recently genetically characterised for the first time two rodent Gongylonema spp., i.e. G. neoplasticum from the black rat (Rattus rattus (Linnaeus)) on Okinawa Island, Japan, and G. aegypti Ashour \& Lewis, 1986 from the Arabian spiny mouse Acomys dimidiatus (Cretzschmar, 1826) on the Sinai Peninsula, Egypt, disclosing their distinctness but close relatedness (Setsuda et al., 2016). Considering that Rattus norvegicus (Berkenhout) (brown rats) and $R$. rattus, the dominant hosts for G. neoplasticum worldwide (Wells et al., 2015), originated from southern China and Southeast or South Asia (Aplin et al., 2011; Song et al., 2014; Thomson et al., 2014; Puckett et al., 2016), the greatest genetic diversity of their endogenous parasites would be expected to be found in worms collected in Southeast Asia rather than invaded localities beyond South and Southeast Asia (Morand et al., 2015), such as Japan, the sole locality of available molecular data for G. neoplasticum. In the latter case, worms must have survived in their new environment by way of the bottleneck phenomenon, thus leading to lower genetic diversity.

In the present study, specimens of Gongylonema in the stomach of Rattus spp. (R. norvegicus, $R$. exulans (Peale), R. tanezumi (Temminck), R. andamanensis Hinton, and another Rattus sp.), Maxomys surifer (Miller), and Berylmys bowersi (Anderson) collected in Cambodia, Indonesia, Laos, Philippines and 
Thailand were examined for their genetic diversity in their putative native areas.

\section{Materials and methods}

\section{Collection of parasites and morphological observation}

During the last 10 years, a variety of murine rodents (approximately 4,500 individuals of more than 20 species) has been trapped in Cambodia, Laos, Philippines and Thailand to try and understand the role of host species and habitat on helminth species richness and to also answer other ecological and epidemiological questions related to parasitic diseases (e.g. Pakdeenarong et al., 2014; Palmeirim et al., 2014; Chaisiri et al., 2015, 2016; Veciana et al., 2015; Ribas et al., 2016). As part of these studies, specimens of Gongylonema were recorded from various murine hosts (Pakdeenarong et al., 2014; Palmeirim et al., 2014; Chaisiri et al., 2016; Ribas et al., 2016), a portion of which was used for the present study; 114 worms collected from different individuals of five Rattus spp., M. surifer, and B. bowersi trapped in Thailand (11 localities), Cambodia (three localities), Lao PDR (three localities), and Philippines (one locality) during the period February 2008 to August 2014 (Table 1). To increase sampling areas, 13 worms from four brown rats trapped in a wet market in Surabaya city, Indonesia, in September 2017 were included in the present study (Table 1). Individual worms embedded in the gastric mucosa were carefully removed from the tissue using fine forceps and fixed individually in $70 \%$ ethanol.

Nine of the 114 worms chosen from archived survey materials were male. Six male and six female worms displaying no morphological damage were selected for morphological observation. Similarly, six male and three female worms collected in Indonesia were used for morphological examination. Specimens preserved in $70 \%$ ethanol were placed in a clearing solution with glycerol and lactic acid, and observed under a light microscope. Figures were drawn with the aid of a camera lucida. Measurements were performed on these drawn figures using a digital curvimeter type S (Uchida Yoko, Tokyo, Japan) when necessary.

DNA extraction, polymerase chain reaction (PCR), and sequencing

The middle 1/5-1/3 section of 109 female worms and 2.5-mm long segments of two male worms were individually used for DNA extraction. Each sample was washed three times in distilled water, placed in a clean 1.5-ml plastic tube, freeze-dried (freeze dryer model EYELA FD-5N; Tokyo Rikakikai Co., Bunkyo-ku, Tokyo, Japan), then crushed with an individual clean plastic pestle. Parasite DNAs were extracted separately from these samples using an Illustra ${ }^{\mathrm{TM}}$ tissue and cells genomicPrep Mini Spin Kit (GE Healthcare UK, Buckinghamshire, UK) according to the manufacturer's instructions.

PCR amplification of overlapping rDNA fragments was performed in a $20-\mu \mathrm{l}$ volume containing a DNA polymerase, Blend Taq-Plus- (TOYOBO, Dojima

Table 1 Gongylonema neoplasticum worms examined in the present study

\begin{tabular}{|c|c|c|c|c|c|c|}
\hline Host rodent speceis & Thailand $^{\mathrm{a}}$ & Cambodia $^{\mathrm{a}}$ & $\operatorname{Laos}^{\mathrm{a}}$ & Philippines $^{\mathrm{a}}$ & Indonesia $^{\mathrm{b}}$ & Total \\
\hline Rattus norvegicus & $29(25)$ & $2(1)$ & & & $13(4)$ & $44(30)$ \\
\hline Rattus exulans & $10(1)$ & $25(7)$ & $2(1)$ & & & $37(9)$ \\
\hline Rattus tanezumi & $10(4)$ & $20(3)$ & & $1(1)$ & & $31(8)$ \\
\hline Rattus andamanensis & $2(2)$ & & & & & $2(2)$ \\
\hline Rattus sp. & & & $1(1)$ & $1(1)$ & & $2(2)$ \\
\hline Maxomys surifer & $5(3)$ & $2(0)$ & & & & $7(3)$ \\
\hline Niviventer fulvescens & & $3(0)$ & & & & $3(0)$ \\
\hline Berylmys bowersi & $1(1)$ & & & & & $1(1)$ \\
\hline Total & $57(36)$ & $52(11)$ & $3(2)$ & $2(2)$ & $13(4)$ & $127(55)$ \\
\hline
\end{tabular}

${ }^{a}$ Number of studied worms from different rodent individuals except for Indonesia (Number of worms reactive to PCR amplification of the rDNA and/or cox 1 mtDNA fragments). In Indonesia ${ }^{b}, 17$ worms were collected from four rats; nine and four worms from two rats were used for morphological and molecular genetic analyses 
Hama, Osaka, Japan), and universal eukaryotic primer pairs as previously described (Makouloutou et al., 2013a). PCR products for sequencing were purified using a FastGene Gel/PCR Extraction Kit (NIPPON Genetics Co., Tokyo, Japan). Following direct sequencing of PCR amplicons, sequences were assembled manually with the aid of the CLUSTAL $\mathrm{W}$ multiple alignment program (Thompson et al., 1994). For rDNA segments containing the internal transcribed spacer (ITS) regions, the amplicon was cloned into a plasmid vector, pTA2 (TArget Clone ${ }^{\mathrm{TM}}$; TOYOBO), and transformed into Escherichia coli JM109 cells (TOYOBO) according to the manufacturer's instructions. Following propagation, the plasmid DNA was extracted using a FastGene Plasmid Mini Kit (NIPPON Genetics Co.) and inserts from multiple independent clones, at least three, were sequenced using universal M13 forward and reverse primers.

The cox 1 region of mtDNA was amplified by two different primer pairs as follows: (i) Gpul_Cox1-303F (5'-GGC TCC TGA GAT GGC TTT TC- $3^{\prime}$ ) and Gpul_Cox1-R (5'-ATG AAA ATG TGC CAC TAC ATA ATA TGT ATC-3'); and (ii) Gpul_Cox1-403F (5'-CCT GGT GGT AGC TGA ACT TT-3') and Gpul_Cox1-906R (5'-GCC CCA AAC AGA CGT ACC TA-3'). These primers were designed using online software 'Primer3web ver.4.0.0' (Untergasser et al., 2012) and referring to a complete cox 1 nucleotide sequence of G. pulchrum (DDBJ/EMBL/ GenBank: KM264298; Liu et al., 2015). PCRs were conducted in a thermal cycler using the following cycling protocol: $3 \mathrm{~min}$ at $94^{\circ} \mathrm{C}$, followed by 40 cycles at $94^{\circ} \mathrm{C}$ for $45 \mathrm{~s}, 48^{\circ} \mathrm{C}$ for $1 \mathrm{~min}$, and $72^{\circ} \mathrm{C}$ for $1 \mathrm{~min}$, then a final extension at $72^{\circ} \mathrm{C}$ for $7 \mathrm{~min}$. For Indonesian worms, another primer pair, Gpul_Cox1F (5'-GTG GTT TTG GTA ATT GAA TGC TA-3') and Gpul_Cox1-R, was used to amplify cox 1 nucleotide sequences, according to Varcasia et al. (2017). Amplicons were sequenced after purification as described above. For sequencing of 868 bp or 905 bp long cox 1 products, which included $50 \mathrm{bp}$ or $53 \mathrm{bp}$ long primer-annealing areas, respectively, the five PCR amplification primers detailed above were used.

The nucleotide sequences reported in the present study are available from the DDBJ/EMBL/GenBank databases under the accession numbers LC331001LC331051 and LC334451-LC334454. Voucher specimens for these DNA analyses were deposited in the National Museum of Nature and Science, Tokyo, Japan, under the accession numbers As4306-As4423.

\section{Phylogenetic analysis}

For phylogenetic analysis, the newly obtained cox 1 sequences (818 bp in length) of Gongylonema worms examined in the present study and those of the same genus retrieved from the DDBJ/EMBL/GenBank databases were used. Spirocerca lupi (Rudolphi, 1809) (Spirurida: Thelaziidae; GenBank: KC305876), Dirofilaria repens Railliet \& Henry, 1911 (Spirurida: Onchocercidae; GenBank: KX265048), and Onchocerca volvulus (Leuckart, 1893) (Spirurida: Onchocercidae; GenBank: AP017695) were retrieved from the databases and used as an outgroup for the construction of the phylogenetic tree. Maximum likelihood (ML) analysis was performed with the program PhyML (Guindon \& Gascuel, 2003; Dereeper et al., 2008) provided on the 'phylogeny.fr' website (http://www.phylogeny.fr/) using 818 characters, of which 258 were variable. The probability of inferred branches was assessed by the approximate likelihood ratio test (aLRT), an alternative to the non-parametric bootstrap estimation of branch support (Anisimova \& Gascuel, 2006).

\section{coxl haplotype analysis}

The relationships of different haplotypes based on 369 bp long cox 1 nucleotide sequences were visualised using an automated haplotype network layout and visualisation software, HapStar, downloaded at http:// fo.am/hapstar (Teacher \& Griffiths, 2011).

\section{Results}

\section{Morphology of G. neoplasticum from Asian rats}

The number of worms embedded in the gastric mucosa of each rat selected for this study from archived survey materials (a total of 114 rats of seven different species trapped at 18 localities in four countries) ranged from a few to several; a single worm from each rat was used (Table 1). In addition, nine worms from two brown rats trapped in Surabaya city, Indonesia, were used for morphological observation. Worms showed marked sexual dimorphism, evident in worm sizes (distinctly 


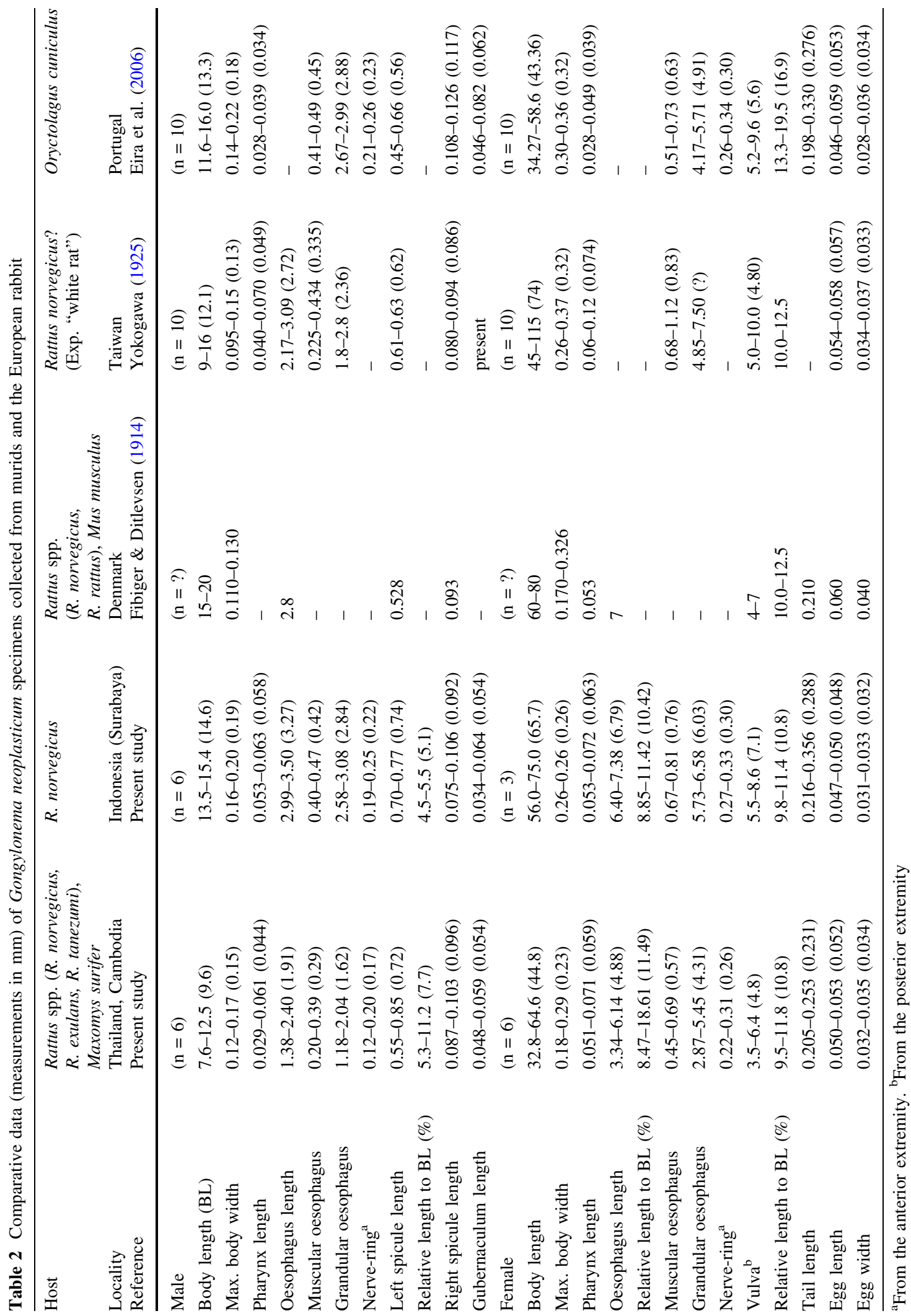




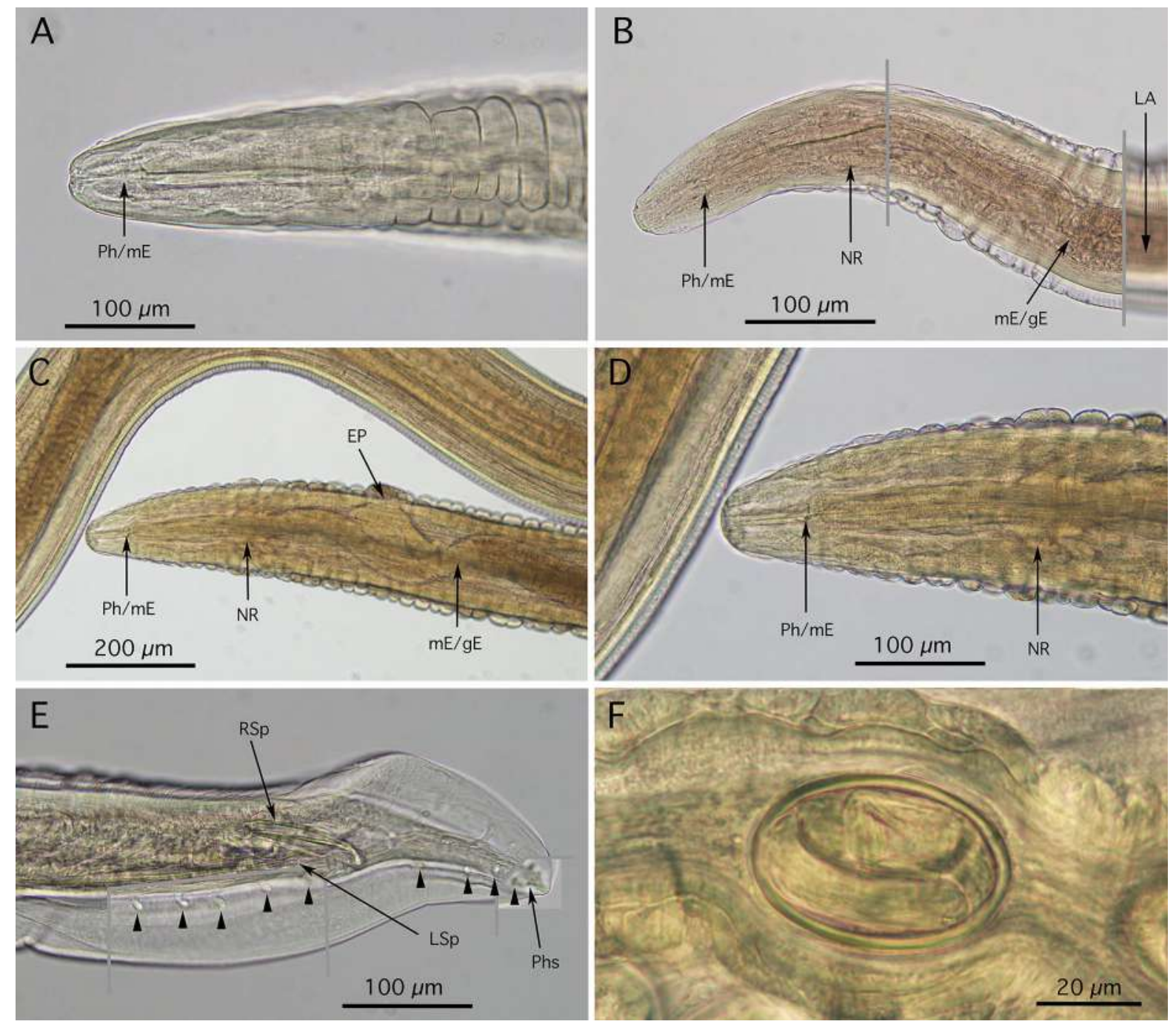

Fig. 1 Gongylonema neoplasticum from Asian rats. A, B, Male, anterior extremity; C, D, Female, anterior extremity; E, Male, posterior extremity, dorsal view; F, intrauterine egg. Photographs B and E are composed of three segments of photographs taken at different depths, marked by gray lines. Abbreviations: EP, excretory pore; LA, lateral ala; LSp, left spicule; mE/gE, the border between muscular oesophagus and glandular oesophagus; NR, nerve-ring; $\mathrm{Ph} / \mathrm{mE}$, the border between pharynx and muscular oesophagus; Phs, phasmid; RSp, right spicule. Arrowheads indicate caudal papillae

smaller sizes of male worms; see Table 2) and differently developed cuticular bosses in the anterior part of the body (poor in male worms and well developed in female worms; see Fig. 1). Mouth opening was connected to the short pharynx, then followed by the muscular and glandular oesophagi, and intestine. Male worms with asymmetric caudal alae had eight pairs of caudal papillae (four precloacal and four post-cloacal), in addition to a pair of phasmids near the posterior extremity. One of six male worms had an additional caudal papilla which was located at the anteriormost position of the pre-cloacal papillae on the left side (Fig. 1E). Male worms possessed a long left and a short right spicule (Fig. 1E). Left spicules were fine thread-like with round distal ends, whereas right spicules and gubernacula were squat. Measurements of the collected worms were well coincident with those of $G$. neoplasticum recorded in earlier studies (Table 2). 


\section{rDNA of G. neoplasticum from Asian rats of different origins}

Following a preliminary reactivity check of rDNA segment amplification by PCR, the rDNA nucleotide sequences of several arbitrarily chosen worms were sequenced (Table 3); 5,649 bp in length from near the $5^{\prime}$-terminus of $18 \mathrm{~S}$ to $28 \mathrm{~S}$ rDNA was comprised of 1,814 bp long partial 18S rDNA, 540 bp long ITS1, 158 bp long 5.8S rDNA, 478 bp long ITS2, and 2,659 bp long partial $28 \mathrm{~S}$ rDNA. The nucleotide sequences of different worms were almost completely identical to one another, as well as to male and female worms of G. neoplasticum from the black rat in Okinawa, Japan (DDBJ/EMBL/GenBank: LC026032 and LC026033; Setsuda et al., 2016). The few nucleotide substitutions observed were located at positions 437, 579, 814 and 1,019 of the 28S rDNA (Table 4). cox 1 of G. neoplasticum from Asian rats of different origins

A partial cox 1 region, 818 bp or 852 bp in length, was successfully sequenced in 55 of the collected worms (Table 5), showing 24 haplotypes with mostly only a few nucleotide substitutions and a maximum of $15(1.83 \%)$ nucleotide substitutions. The most prominent haplotypes with one or no nucleotide substitution were found in 27 worms (49.1\%) of different localities and host origins. In an ML phylogenetic tree constructed on the basis of these 818 bp long cox 1 sequences, all specimens of $G$. neoplasticum from Asian rats formed a well-supported clade, which was distinct from G. aegypti from the Arabian spiny mouse in Egypt, a clade of $G$. pulchrum from domestic ruminants in Japan and China, and G. nepalensis from ruminants on Sardinia Island, Italy (Fig. 2). To define

Table 3 Gongylonema neoplasticum worms examined for the rDNA nucleotide sequences, Worms reactive to PCR amplification of rDNA nucleotide fragments are shown by worm ID number. Specimens with numbers in bold showed a few nucleotide substitutions in the 28S rDNA (see Table 4)

\begin{tabular}{|c|c|c|c|}
\hline Host rodent species & Thailand & Cambodia & Philippines \\
\hline Rattus norvegicus & $\# 51, \# 76, \# 79, \# 82, \# 85, \# 87$ & & \\
\hline Rattus exulans & & $\# 17, \# \mathbf{2 1}, \# 90$ & \\
\hline Rattus tanezumi & $\# 36, \# 40, \# 49$ & & \\
\hline Rattus andamanensis & $\# 45$ & & \\
\hline Rattus sp. & & & \#59 \\
\hline Maxomys surifer & $\# 52$ & & \\
\hline Berylmys bowersi & \#38 & & \\
\hline
\end{tabular}

Table 4 Nucleotide variations in the 28S rDNA of Gongylonema neoplasticum of different origins. Worms with long rDNA nucleotide sequences successfully amplified by PCR are shown

\begin{tabular}{|c|c|c|c|c|c|c|c|}
\hline \multirow[t]{2}{*}{ Worm ID } & \multirow{2}{*}{$\begin{array}{l}\text { DDBJ/ EMBL/ } \\
\text { GenBank ID }\end{array}$} & \multirow[t]{2}{*}{ Host } & \multirow[t]{2}{*}{ Locality } & \multicolumn{4}{|c|}{$28 \mathrm{~S} \mathrm{rDNA}^{\mathrm{a}}$} \\
\hline & & & & 437 & 579 & 814 & 1019 \\
\hline$\# 17, \# 51, \# 59$ & LC330994-LC330996 & $\begin{array}{l}R . \text { norvegicus, } R \text {. exulans, } \\
\text { Rattus } \mathrm{sp} .\end{array}$ & $\begin{array}{l}\text { Thailand, Cambodia, } \\
\text { Philippines }\end{array}$ & A & $\mathrm{C}$ & $\mathrm{C}$ & $\mathrm{C}$ \\
\hline$\# 21$ & LC330997 & Rattus exulans & Cambodia & . & . & $\mathrm{T}$ & . \\
\hline \#38 & LC330998 & Berylmys bowersi & Thailand & . & . & $\mathrm{T}$ & . \\
\hline \#49 & LC330999 & Rattus tanezumi & Thailand & . & $\mathrm{T}$ & . & . \\
\hline$\# 82$ & LC331000 & Rattus norvegicus & Thailand & . & . & . & $\mathrm{T}$ \\
\hline $\begin{array}{l}\text { G. neoplasticum } \\
\text { JPN }\end{array}$ & LC026032, LC026033 & Rattus rattus & Japan & $\mathrm{C}$ & . & . & . \\
\hline
\end{tabular}

${ }^{a}$ Relative nucleotide position to the $28 \mathrm{~S}$ rDNA of a Japanese isolate of G. neoplasticum (DDBJ/EMBL/GenBank: LC026032) 
Table 5 Gongylonema neoplasticum worms examined for the cox $1 \mathrm{mtDNA}$ nucleotide sequences

\begin{tabular}{|c|c|c|c|c|c|}
\hline Host rodent species & Thailand & Cambodia & Laos & Philippines & Indonesia \\
\hline Rattus norvegicus & $\begin{array}{l}\# 51, \# 62, \# 63, \# 65, \# 66, \# 67, \# 69, \\
\quad \# 70, \# 71, \# 72, \# 73, \# 75, \# 76, \# 77, \\
\quad \# 78, \# 79, \# 80, \# 81, \# 82, \# 83, \# 84, \\
\# 85, \# 86, \# 87, \# 89\end{array}$ & $\# 8$ & & & $\begin{array}{l}\# 161, \# 162, \\
\# 163, \# 164\end{array}$ \\
\hline Rattus exulans & \#95 & $\begin{array}{l}\# 2, \# 7, \# 17, \# 21, \# 96 \text {, } \\
\quad \# 97, \# 98\end{array}$ & $\# 47$ & & \\
\hline Rattus tanezumi & $\# 36, \# 40, \# 49, \# 53$ & $\# 15, \# 28, \# 30$ & & \#57 & \\
\hline Rattus andamanensis & $\# 45, \# 50$ & & & & \\
\hline Rattus sp. & & & \#123 & \#59 & \\
\hline Maxomys surifer & $\# 41, \# 42, \# 52$ & & & & \\
\hline Berylmys bowersi & \#38 & & & & \\
\hline
\end{tabular}

the molecular genetic relationship with a specimen of G. neoplasticum from the black rat in Okinawa, Japan (DDBJ/EMBL/GenBank: LC026049; Setsuda et al., 2016), 369 bp long cox 1 segments (constituting the 450th nucleotide through to the $3^{\prime}$-terminus of the 818 bp long cox 1 fragments) of the 55 successfully sequenced worms were analysed by the HapStar network illustration (Fig. 3). These 369 bp long cox 1 segments contained the majority of nucleotide substitutions (92 sites), whereas the anterior 449 bp long segments contained only 24 nucleotide substitution sites, when specimens of G. pulchrum, G. nepalensis, G. aegypti, G. neoplasticum and Gongylonema collected in the present study were compared. When the 55 specimens Gongylonema collected in the present study were compared, the anterior 449 bp long cox 1 segment contained 16 nucleotide substitution sites, and the posterior $369 \mathrm{bp}$ long cox 1 segment contained 20 nucleotide substitution sites. Subsequent analyses with the 369 bp long cox 1 segments showed 19 haplotypes; the most prominent haplotype was found in 30 worms (54.6\%). Translation of amino acid (aa) sequences from the $818 \mathrm{bp}$ and $369 \mathrm{bp}$ long cox 1 nucleotide sequences resulted in 17 types of 272 aa sequences and 10 types of 123 aa sequences, respectively. The most prominent amino acid sequence type in each analysis was found in $56.4 \%(31 / 55 ; 272$ aa sequences) and $83.6 \%$ (46/55; 123 aa sequences) of analysed worms. The cox 1 haplotype of G. neoplasticum collected in Okinawa, Japan, was identical to the most prominent haplotype of the Gongylonema worms collected in Southeast Asian countries (Fig. 3), and its amino acid sequence, as well as that of G. aegypti, was identical to the most prominent amino acid sequence type in worms collected in the present study.

\section{Discussion}

The Gongylonema worms collected in the present study appear to be a single species, G. neoplasticum, based on morphological characters such as continuous lateral alae, numbers of caudal papillae (four pairs of pre- and four pairs of post-cloacal ones), poor development of cuticular bosses on the anterior surface of male worms in contrast to developed ones in female worms (Fig. 1), in addition to specimen measurements (Table 2). Natural definitive hosts of the species include not only $R$. norvegicus and $R$. rattus, but also Bunomys chrysocomus (Hoffmann) (yellow-haired hill rat), Bandicota savilei Thomas (Savile's bandicoot rat), Maxomys surifer (red spiny rat), Mus caroli (Ryukyu mouse), Mus cervicolor Hodgson (fawn-colored mouse), Mus cookii Ryley (Cook's mouse), Niviventer fulvescens (Gray) (chestnut white-bellied rat), Rattus exulans (Polynesian rat), Rattus losea (Swinhoe) (lesser ricefield rat), Rattus tanezumi (Asian house rat), Rattus tiomanicus (Miller) (Malayan field rat) and Oryctolagus cuniculus (Linnaeus) (European rabbit) (Fibiger \& Ditlevsen, 1914; Yokogawa, 1925; Kruidenier \& Peebles, 1958; Skrjabin et al., 1967; Singh \& Cheong, 1971; Yap et al., 1977; Leong et al., 1979; Krishnasamy et al., 1980; Jueco \& Zabala, 1990; Hasegawa \& Syafruddin, 1995; Eira et al., 2006; Syed-Arnex \& Mohd Zain, 2006; Paramasvaran et al., 2009; Dewi, 2011; Chaisiri et al., 


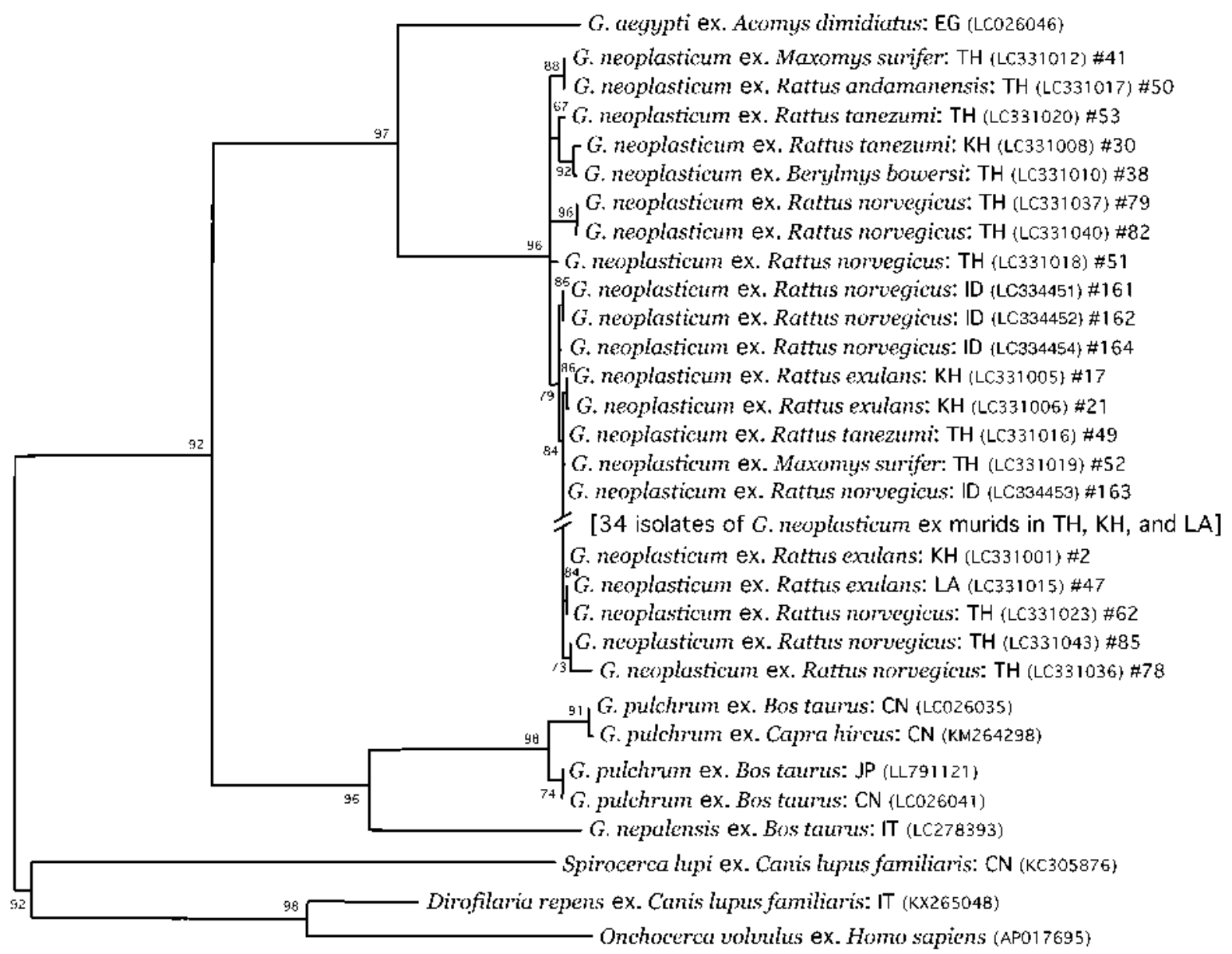

0.09 substitutions / site

Fig. 2 Maximum Likelihood phylogenetic tree based on 818 bp long $\operatorname{cox} 1$ nucleotide sequences. All nucleotide sequences of Gongylonema neoplasticum shown in the figure are newly generated in the present study, with 27 isolates omitted for simplification. The species name of isolates is followed by host species, country of collection, DDBJ/EMBL/GenBank accession number, and worm ID number. Abbreviations: CN, China; EG, Egypt; IT, Italy; JP, Japan; KH, Cambodia; LA, Laos; PH, Philippines; and TH, Thailand

2012; Paramasvaran et al., 2012; Dewi \& Purwaningsih, 2013). As detailed measurements of specimens from different hosts or localities have not always been recorded, possible variations of phenotypical characters of $G$. neoplasticum have not been assessed to any great extent. Without any knowledge of the genetic background of worms under investigation, i.e. worms of a single species or multiple species, it is impossible to explain the significance of possible phenotypical variations. Due to this reason, Kinsella et al. (2016) stressed the importance of acquiring molecular data in addition to phenotypical character data from collected parasites to understand the systematics of rodent Gongylonema spp.
The present study aimed to characterise the rDNA and cox 1 nucleotide sequences of G. neoplasticum based on material collected as part of several helminth surveys conducted in Thailand, Cambodia, Laos and Philippines during the period February 2008 to August 2014, with additional worms from Indonesia (Pakdeenarong et al., 2014; Palmeirim et al., 2014; Chaisiri et al., 2015, 2016; Veciana et al., 2015; Ribas et al., 2016). The majority of worms collected in these surveys had previously undergone microscopic observation for their specific identification. Furthermore, a portion of the worms had been preserved for several years, dating from February 2008 through to the spring of 2016. Therefore, at the outset of our study, we were 


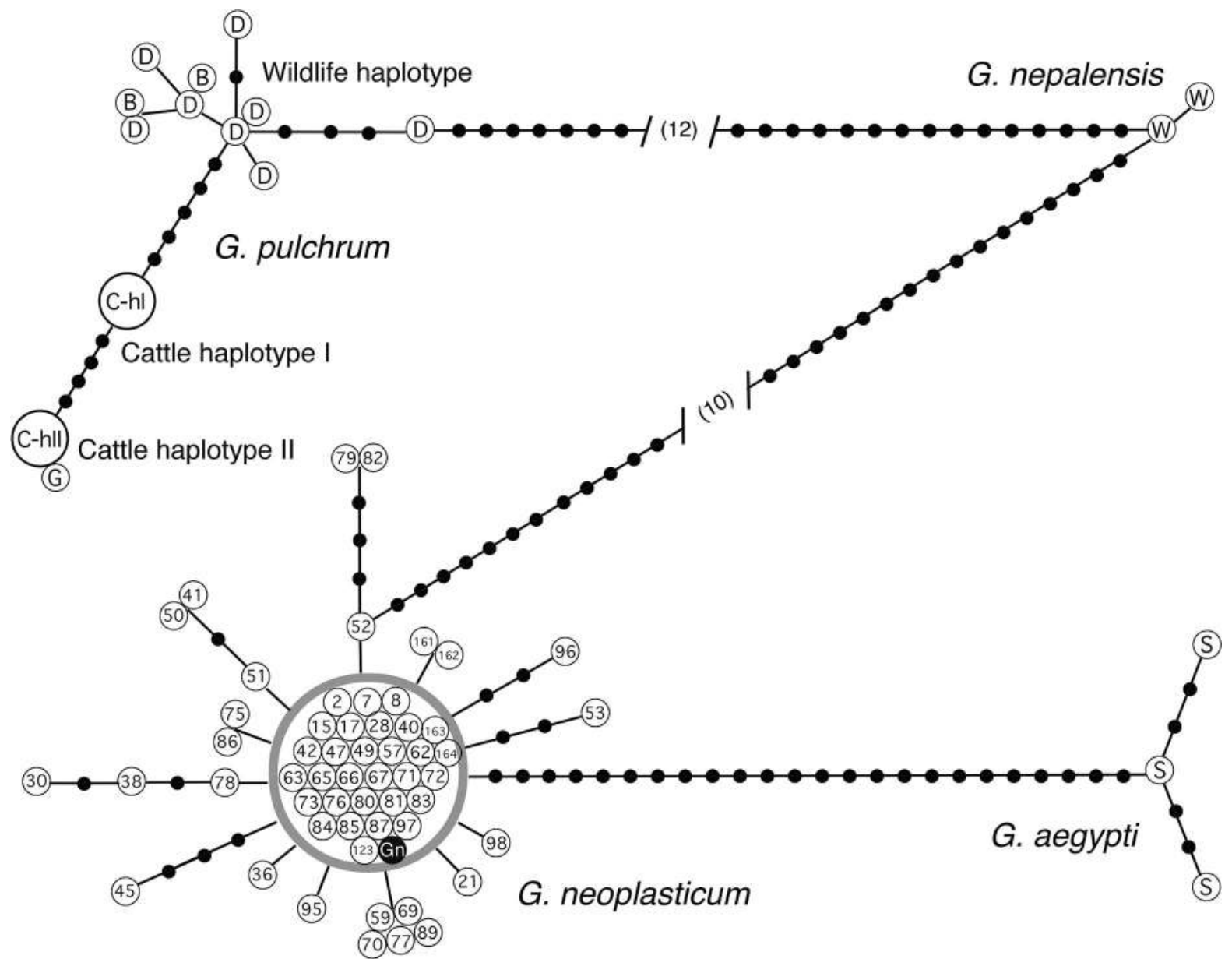

Fig. 3 Relationships of cox 1 haplotypes of Gongylonema neoplasticum recovered from Asian rats, based on 369 bp long nucleotide sequences. Numbers in the circles for G. neoplasticum indicate the worm ID number, while letters in the circles for other Gongylonema spp. indicate the host animal (B, wild boar; C-hI, cattle with cox 1 haplotype I G. pulchrum; C-hII, cattle with cox 1 haplotype II G. pulchrum; D, sika deer; G, goat; S, spiny mouse; W, water buffalo). 'Gn' in the prominent haplotype of G. neoplasticum indicates the worm collected in Okinawa, Japan (DDBJ/EMBL/GenBank: LC026049)

aware that these past treatments of the samples could negatively affect the PCR amplification of rDNA and cox 1 mtDNA fragments. Indeed, successful cox 1 sequencing was achieved in $47.7 \%$ (51/107) of examined worms from archived survey materials.

Using several arbitrarily chosen worms, almost identical rDNA sequences (including the ITS regions) with only a few nucleotide substitutions over a length of 5,649 bp were obtained. The ITS regions are highly variable nuclear DNA regions useful for species and strain separation. In the case of G. pulchrum, numerous repeats of a few to several nucleotide units often occur in the ITS regions, and intraspecific as well as intra-individual variations of these nucleotide repeats have been seen in addition to interspecific variations (Makouloutou et al., 2013a; Setsuda et al., 2016). Similarly, G. neoplasticum collected from Southeast Asian rats exhibited such nucleotide repeats in the ITS regions, but lacked variation in the number of repeats of certain nucleotide units. The rDNA nucleotide sequences of G. neoplasticum worms collected in the present study were almost completely identical (only a few nucleotides differed) to those of $G$. neoplasticum isolated in Okinawa, Japan (DDBJ/EMBL/GenBank: LC026032 and LC026033). Therefore, as the unique rDNA sequences of $G$. neoplasticum and those of congeners such as G. aegypti, G. pulchrum and $G$. nepalensis were discussed in our previous study 
(Setsuda et al., 2016), we do not repeat that discussion here.

Makouloutou et al. (2013a) reported a great variety of cox 1 gene nucleotide sequences (seven cox 1 haplotypes), but only a small amount of amino acid sequence variation, in G. pulchrum isolated from wild mammals such as deer, wild boars and Japanese macaques in Japan. This is in contrast to only two major cox 1 haplotypes in cattle in Japan, China (Inner Mongolia) and Iran (Halajian et al., 2010; Makouloutou et al., 2013a; Setsuda et al., 2016). This might reflect the fact that endemic mammals have a parasite population with a spectrum of genetic diversity, whereas mammals translocated by human activities have a parasite population with little genetic diversity. Considering that G. neoplasticum is currently cosmopolitan in distribution with an unintended introduction of its rodent hosts as a consequence of recent global trade, and that Rattus spp. such as $R$. norvegicus, $R$. rattus, $R$. tanezumi, and $R$. exulans have been shown to originate in southern China and Southeast or South Asia (Aplin et al., 2011; Song et al., 2014; Thomson et al., 2014; Puckett et al., 2016), it is reasonable to propose that G. neoplasticum examined here is likely to have a maximum spectrum of genetic diversity in fast-evolving mtDNA genes such as $\operatorname{cox} 1$.

As hypothesised above, the cox 1 nucleotide sequences of $G$. neoplasticum examined in the present study showed a high genetic diversity, represented by the presence of 24 haplotypes (based on $818 \mathrm{bp}$ long sequences) or 19 haplotypes (based on 369 bp long sequences) regardless of collection site (country) and host rat species (Fig. 3). When these 818 bp and 369 bp long nucleotide sequences were translated to amino acid sequences, 17 and 10 types of sequences were differentiated, with the most prominent sequence found in 56.4\% (31/55) and 83.6\% (46/55) of analysed worms, respectively. This finding indicates that most of the $\operatorname{cox} 1$ nucleotide substitutions of samples of $G$. neoplasticum examined in the present study occurred at the third nucleotide of codons, as previously observed in an earlier study (Setsuda et al., 2016). As far as examined here, similar to G. pulchrum isolated from wild mammals in Japan, there is no suggestion of colonisation of special haplotypes of $G$. neoplasticum at defined localities nor prevalence of special haplotypes in defined rat species. Since known intermediate hosts (e.g. common insects such as cockroaches and beetles (Fibiger \& Ditlevsen, 1914; Yokogawa, 1925; Dittrich, 1963) and definitive hosts (different rat species) for G. neoplasticum are sympatric and probably have comparable susceptibilities to infection with this spirurid nematode, the current wide distribution of genetically heterogeneous $G$. neoplasticum with different cox 1 haplotypes in Southeast Asia could be a natural outcome. On the contrary, the lower genetic heterogeneity of G. neoplasticum in localities where black and brown rats were introduced as a consequence of recent global trade is highly predictable in view of the bottleneck phenomenon (Morand et al., 2015).

A possible genetic spectrum of G. neoplasticum from rats distributed in their original endemic area, Southeast Asia, is of great importance, particularly when only a single (or a few) Gongylonema worm from a rodent host at a certain locality is collected and analysed for its genetic uniqueness. As mentioned earlier, more than a dozen rodent Gongylonema spp. have been recorded to date. The molecular characterisation of each species should facilitate the phenotypical characterisation which often shows variation. Such efforts may detect substantial specific diversities of rodent Gongylonema spp., as previously communicated by Kinsella et al. (2016).

Funding This study was supported in part by JSPS KAKENHI grants (nos. 15K07722 and 15H05261) and Grant-in-Aid for International Collaboration Research in Asia 2016 from Heiwa Nakajima Foundation (HS).

\section{Compliance with ethical standards}

Conflict of interest The authors declare that they have no conflict of interest.

Ethical approval All applicable institutional, national and international guidelines for the care and use of animals were followed.

\section{References}

Anderson, R. C. (1992). Nematode parasites of vertebrates; their development and transmission. Oxon, Wallingford, UK: CAB International.

Anisimova, M., \& Gascuel, O. (2006). Approximate likelihoodratio test for branches: a fast, accurate, and powerful alternative. Systematic Biology, 55, 539-552.

Aplin, K. P., Suzuki, H., Chinen, A. A., Chesser, R. T., Have, J., Donnellan, S. C., et al. (2011). Multiple geographic origins 
of commensalism and complex dispersal history of black rats. PLoS One, 6, e26357.

Ashour, A. A., \& Lewis, J. W. (1986). Gongylonema aegypti $\mathrm{n}$. sp. (Nematoda: Thelaziidae) from Egyptian rodents. Systematic Parasitology, 8, 199-206.

Baylis, H. A., Sheather, L. A., \& Andrews, W. H. (1926a). Further experiments with the Gongylonema of cattle. Journal of Tropical Medicine and Hygiene, 29, 194-196.

Baylis, H. A., Sheather, L. A., \& Andrews, W. H. (1926b). Further experiments with the Gongylonema of cattle-II. Journal of Tropical Medicine and Hygiene, 29, 346-349.

Chabaud, A. G. (2009). Spirurida: Spiruroidea, Habronematoidea and Acuarioidea. In: Anderson, R. C., Chabaud, A. G. \& Willmott, S. (Eds), Keys to the nematode parasites of vertebrates; archival volume. Oxfordshire: $\mathrm{CAB}$ International, pp. 361-390.

Chaisiri, K., Chaeychomsri, W., Siruntawineti, J., Ribas, A., Herbreteau, V., \& Morand, S. (2012). Diversity of gastrointestinal helminths among murid rodents from northern and northeastern Thailand. Southeast Asian Journal of Tropical Medicine and Public Health, 43, 21-28.

Chaisiri, K., Siribat, P., Ribas, A., \& Morand, S. (2015). Potentially zoonotic helminthiases of murid rodents from the Indo-Chinese Peninsula: impact of habitat and the risk of human infection. Vector-borne and Zoonotic Diseases, $15,73-85$.

Chaisiri, K., Chou, M., Siew, C. C., Morand, S., \& Ribas, A. (2016). Gastrointestinal helminth fauna of rodents from Cambodia: emphasizing the community eocology of hostparasite association. Journal of Helminthology, 91, 726-738.

Dereeper, A., Guignon, V., Blanc, G., Audic, S., Buffet, S., Chevenet, F., et al. (2008). Phylogeny.fr: robust phylogenetic analysis for the non-specialist. Nucleic Acids Research, 36, 465-469.

Dewi, K. (2011). Nematode parasites of rats in Pakuli Village, Gumbara Subdistrict, Donggala District, Central Sulawesi. Jurnal Ekologi Kesehatan, 10, 38-41 (In Indonesian with English summary).

Dewi, K., \& Purwaningsih, E. (2013). Helminth parasites on rats on in rubber plantation in Bogorejo Village, Gedongtataan Subdistrict, Pesawaran Regency, Lampung and their zoonotic review. Zoo Indonesia, 22, 1-7 (In Indonesian with English summary).

Diouf, M., Bâ, C. T., Marchand, B., \& Vassiliadès, G. (1997). Gongylonema madeleinensis n. sp. (Nematoda: Spiruroidea), from Mastomys erythroleucus (Rodentia) from a Senegalese island. Journal of Parasitology, 83, 706-708.

Dittrich, L. (1963). Gongylonema neoplasticum (Fibiger und Ditlevsen, 1914) bei Ratten und Schaben. Berliner und Münchener Tierärztliche Wochenschrift, 76, 12-13.

Eira, C., Miquel, J., Vingada, J., \& Torres, J. (2006). Natural infection of Oryctolagus cuniculus (Lagomorpha, Leporidae) by Gongylonema neoplasticum (Nematoda, Gongylonematidae) in Portugal. Acta Parasitogica, 51, 119-122.

Fibiger, J., \& Ditlevsen, H. (1914). Contributions to the biology and morphology of Spiroptera (Gongylonema) neoplastica n. sp. Mindeskr Japetus Steenstrup fødsel, 25, 1-28.

Guindon, S., \& Gascuel, O. (2003). A simple, fast, and accurate algorithm to estimate large phylogenies by maximum likelihood. Systematic Biology, 52, 696-704.
Gupta, S. P., \& Trivedi, K. K. (1985). Nematode parasites of vertebrates. A new nematode, Gongylonema fotedari sp. nov. (family: Spiruridae Oerley, 1985) from Indian mole rat Bandicota bengalensis from Lucknow, U.P. Indian Journal of Helminthology, 37, 100-108.

Halajian, A., Eslami, A., Salehi, N., Ashraft-Helan, J., \& Sato, H. (2010). Incidence and genetic characterization of Gongylonema pulchrum in cattle slaughtered in Mazandaran Province, northern Iran. Iranian Journal of Parasitology, 5, 10-18.

Hasegawa, H., \& Syafruddin, (1995). Nematode fauna of the two sympatric rats Rattus rattus and $R$. exulans, in Kao District, Halmahera Island, Indonesia. Journal of Helminthological Society of Washington, 62, 27-31.

Jueco, N. L., \& Zabala, Z. R. (1990). The nematodes of Rattus norvegicus and Rattus rattus mindanensis. Philippine Journal of Veterinary Medicine, 27, 39-46.

Kinsella, J. M., Robles, M. R., Whitney, C., \& Preisser, W. C. (2016). A review of Gongylonema spp. (Nematoda: Gongylonematidae) in North American rodents with description of a new species from the cotton rat, Sigmodon hispidus (Mammalia: Cricetidae). Zootaxa, 4107, 277-284.

Krishnasamy, M., Singh, K. I., Ambu, S., \& Ramachandran, P. (1980). Seasonal prevalence of the helminth fauna of the wood rat Rattus tiomanicus (Miller) in west Malaysia. Folia Parasitologica, 27, 231-235.

Kruidenier, F. J., \& Peebles, C. R. (1958). Gongylonema of rodents: G. neoplasticum (redefinition); G. dipodomysis n. sp. and G. peromysci n. sp. Transactions of the American Microscopical Society, 67, 307-315.

Leong, T. S., Lim, B. L., Yap, L. F., \& Krishnasamy, M. (1979). Parasite fauna of the house rat Rattus rattus diardii in Kuala Lumpur and nearby villages. Southeast Asian Journal of Tropical Medicine and Public Health, 10, 122-126.

Lichtenfels, J. R. (1971). Morphological variation in the gullet nematode, Gongylonema pulchrum Molin, 1857, from eight species of definitive hosts with a consideration of Gongylonema from Macaca spp. Journal of Parasitology, 57, 348-355.

Liu, G. H., Jia, Y. Q., Wang, Y. N., Zhao, G. H., \& Zhu, X. Q. (2015). The complete mitochondrial genome of the gullet worm Gongylonema pulchrum: gene content, arrangement, composition and phylogenetic implications. Parasites \& Vectors, 8, 100.

Lucker, J. T. (1932). Some cross transmission experiments with Gongylonema of ruminant origin. Journal of Parasitology, 19, 134-141.

Makouloutou, P., Setsuda, A., Yokoyama, M., Tsuji, T., Saita, E., Torii, H., et al. (2013a). Genetic variation of Gongylonema pulchrum from wild animals and cattle in Japan based on ribosomal RNA and mitochondrial cytochrome $c$ oxidase I genes. Journal of Helminthology, 87, 326-335.

Makouloutou, P., Rana, H. B., Adhikari, B., Devkota, B., Dhakal, I. P., \& Sato, H. (2013b). A distinct genetic population of Gongylonema pulchrum from water buffaloes in Nepal. Journal of Parasitology, 99, 669-676.

Morand, S., Bordes, F., Chen, H.-W., Claude, J., Cosson, J.-F., Galan, M., et al. (2015). Global parasite and Rattus rodent 
invasions: the consequences for rodent-borne disease. Integrative Zoology, 10, 409-423.

Pakdeenarong, N., Siribat, P., Chaisiri, K., Douangboupha, B., Ribas, A., Chaval, Y., et al. (2014). Helminth communities in murid rodents from southern and northern localities in Lao PDR: the role of habitat and season. Journal of Helminthology, 88, 302-309.

Palmeirim, M., Bordes, F., Chaisiri, K., Siribat, P., Ribas, A., \& Morand, S. (2014). Helminth parasite species richness in rodents from Southeast Asia: role of host species and habitat. Parasitology Research, 113, 3713-3726.

Paramasvaran, S., Sani, R. A., Hassan, L., Kaur, Hanjeet, Krishnasamy, M., Jeffery, J., et al. (2009). Endoparasite fauna of rodents caught in five wet markets in Kuala Lumpur and its potential zoonotic implications. Tropical Biomedicine, 26, 67-72.

Paramasvaran, S., Sani, R. A., Krishnasamy, M., Amal, Nasir M., Hassan, L., Mohd Zain, S. N., et al. (2012). An overview of nematodes infecting urban and wild rats (Muridae) in Malaysia. Malaysian Journal of Veterinary Research, 3, $15-21$.

Puckett, E. E., Park, J., Combs, M., Blum, M. J., Bryant, J. E., Caccone, A., et al. (2016). Global population divergence and admixture of the brown rat (Rattus norvegicus). Proceedings of the Royal Society B, 283, 20161762.

Ransom, B. H., \& Hall, M. C. (1915). The life history of Gongylonema scutatum. Journal of Parasitology, 2, 80-86.

Ribas, A., Saijuntha, W., Agatsuma, T., Thongjun, C., Lamsan, K., \& Poonlaphdecha, S. (2016). Helminths in rodents from wet markets in Thailand. Helminthologia, 53, 326-330.

Sato, H. (2009). Biology and transmission of the gullet worm (Gongylonema pulchrum Molin, 1857). Yamaguchi Journal of Veterinary Medicine, 36, 31-54 (In Japanese with English summary).

Schwartz, B., \& Lucker, J. T. (1931). Experimental transmission of Gongylonema scutatum to pigs. Journal of Parasitology, $18,46$.

Setsuda, A., Da, N., Hasegawa, H., Behnke, J. M., Rana, H. B., \& Sato, H. (2016). Intraspecific and interspecific genetic variation of Gongylonema pulchrum and two rodent Gongylonema spp. (G. aegypti and G. neoplasticum), with the proposal of $G$. nepalensis n. sp. for the isolate in water buffaloes from Nepal. Parasitology Research, 115, 787-795.

Singh, M., \& Cheong, C. (1971). On a collection of nematode parasites from Malayan rats. Southeast Asian Journal of Tropical Medicine and Public Health, 2, 516-522.

Skrjabin, K. I., Sobolev, A. A., \& Ivashkin, V. M. (1967). [Spirurata of animals and man and the diseases caused by them. Part 4. Thelazioidea]. Moscow: Akademiya Nauk SSSR, Gel'mintologicheskaya Laboratoriya Osnovy
Nematodologii, translated from Russian to English by Israel Program for Scientific Translations, Jerusalem in 1971.

Song, Y., Lan, Z., \& Kohn, M. H. (2014). Mitochondrial DNA phylogeography of the Norway rat. PLoS One, 9, e88425.

Syed-Arnex, A. S. K., \& Mohd Zain, S. N. (2006). A study on wild rats and their endoparasite fauna from the Endau Rompin National Park, Johor. Malaysian Journal of Science, 25, 19-39.

Teacher, A. G. F., \& Griffiths, D. J. (2011). HapStar: automated haplotype network layout and visualization. Molecular Ecology Resources, 11, 151-153.

Thompson, J. D., Higgins, D. G., \& Gibson, T. J. (1994). CLUSTAL W: Improving the sensitivity of progressive multiple sequence alignment through sequence weighting, position-specific gap penalties and weight matrix choice. Nucleic Acids Research, 22, 4673-4680.

Thomson, V., Aplin, K. P., Cooper, A., Hisheh, S., Suzuki, H., Maryanto, I., et al. (2014). Molecular genetic evidence for the place of origin of the Pacific rat. Rattus exulans. PLoS One, 9, e91356.

Untergasser, A., Cutcutache, I., Koressaar, T., Ye, J., Faircloth, B. C., Remm, M., \& Rozen, S. G. (2012). Primer 3 - new capabilities and interfaces. Nucleic Acids Research, 40, e115.

Varcasia, A., Scala, A., Zidda, A., Cabras, P. A., Gaglio, G., Tamponi, C., et al. (2017). First record of Gongylonema nepalensis in domestic and wild ruminants in Europe. Veterinary Parasitology, 246, 11-18.

Veciana, M., Bain, O., Morand, S., Chaisiri, K., Douangboupha, B., Miquel, J., et al. (2015). Breinlia (Breinlia) jittapalapongi n. sp. (Nematoda: Filarioidea) from the Asian house rat Rattus tanezumi Temminck in Lao PDR. Systematic Parasitology, 90, 237-245.

Wells, K., O’Hara, R. B., Morand, S., Lessard, J.-P., \& Ribas, A. (2015). The importance of parasite geography and spillover effects for global patterns of host-parasite association in two invasive species. Diversity and Distributions, 21, $477-486$.

Yamaguti, S. (1961). Systema Helminthum, Volume 3. The nematodes of vertebrates. New York: Interscience Publishers.

Yap, L. F., Lim, B. L., de Witt, G. F., Krishnasamy, M., Sivanandam, S., \& Foong, P. Y. K. (1977). Protozoan and helminth parasites of small wild mammals in a new Felda Settlement Jenderak Utara, Central Pahang, Peninsula Malaysia. Southeast Asian Journal of Tropical Medicine and Public Health, 8, 345-353.

Yokogawa, S. (1925). On a new species of nematode, Gongylonema orientale, found in Formosa. Journal of Parasitology, 11, 195-200. 